UDC: 378.14 .796 .01

DOI: https://doi.org/10.24195/2414-4665-2017-8-4

\author{
Vadym Tkachenko, \\ PhD (Candidate of Pedagogical Sciences), senior lecturer, \\ Department of Pedagogy of Higher School and Education Management, \\ Cherkasy National University named after Bohdan Khmelnytskyi, \\ 81, Shevchenko Boulevard, Cherkasy, Ukraine
}

\title{
PECULIARITIES OF FUTURE PHYSICAL EDUCATION TEACHERS' HEALTH SAVING SKILLS FORMATION
}

The research aims to examine the level of future Physical Education teachers' health saving skills maturity by means of implementing theoretical and methodological bases of training based on the interrelation of motivational, content, cognitive, procedural, self-evaluating, reflexive and creative components, as well as by means of using modern approaches to the organization of the educational process. The carried out experiment involving 565 students divided into control and experimental groups has shown that most of the respondents have immature level of skills of using health saving technologies in their work. The process of training future Physical Education teachers should be improved and focused on the development of health saving skills. There should be designed pedagogical conditions contributing to the efficiency of the educational process.

Keywords: teacher, skills, experiment, health, health saving technologies, educational process, physical culture.

\section{Introduction}

Today Ukraine is facing serious political and social transformations which cannot but affect the rethinking of some aspects of higher education. Under modern conditions of the intensive development of the educational process of our state health is one of the main limiting factors.

Due to this modern educational system requires modernization with deep reconsideration of the requirements to the organization of recreation microclimate in the educational environment. Modern tendencies of the development of the national educational system acquire theoretical grounding and practical renewal of the content and methods of specialized training of Physical Education teachers.

Education should be based not only on the fundamental knowledge in a certain area but on the formation of motives of keeping a healthy lifestyle, as well as responsible attitude towards one's own and other people's health. Changes of the values of modern education, concretization of its focus on the significance of healthy way of living have caused changes in the technology of training future Physical Education teachers.

The issues of health saving and recreational technologies was the subject of researches of such domestic scientists as O. Aksionova [1], N. Denysenko [4], O. Dubohai [5], V. Yermolova [6], Yu. Kovalenko [9] and others. The peculiarities of promotion and saving health are discussed in the papers of psychologists, medical workers, sociologists (H. Zaitsev [7], V. Klimova [8], S. Svyrydenko [13] and others). Besides, the bases of health saving education were studied by such researchers as V. Horashchuk [3], O. Dubohai [5], V. Orzhekhovska [12].

The works of V. Lozynskyi [10], Yu. Naumenko [11] and others covered the issue of using health saving technologies in modern educational institutions, reconsidering forms and methods of health saving technologies implementation in the modern world.

The paper aims to examine the level of future Physical Education teachers' skills of using health saving technologies in their work.

The research covers the following tasks: to examine motivational, content, cognitive, procedural, selfevaluating, reflexive, and creative components in terms of investigating the students' skills of using health saving technologies.

\section{Research Methods}

The experiment involved 565 students who were divided into control $(n=280)$ and experimental $(n=285)$ groups.

According to the research tasks we have determined the criteria, content characteristics, indicators, levels and designed a scale of assessing future Physical Education teachers' skills of using health saving technologies in their future work. The levels and the assessment scale are presented in table 1 .

\begin{tabular}{ccc} 
& \multicolumn{2}{c}{ Levels and Assessment Scale } \\
Level & low & medium \\
Scores & $1.00-5.00$ & $5.00-7.50$ \\
& 3.75 & 6.25
\end{tabular}

Table 1.

Level

$$
3.75
$$


We distinguish the following components in the pedagogical model of preparing future Physical Education teachers for using health saving technologies: motivational, content, cognitive, procedural, self-evaluating, reflexive, creative.

The analysis of the experiment results was carried out according to the following scheme: a) checking the qualitative homogeneity of the samples using Wilcoxon signed-rank test [2, 247-250]. The application of this criterion presupposes the measurement of critical points [2, 249-250] according to the samples values $n_{1}, n_{2}$ and the level of significance $\alpha$. In our case $n_{1}=280, n_{2}=285, \alpha=0.05$. The results are presented in table 2 .

Critical Values for Wilcoxon Signed-Rank Test ( $\alpha=0.05$ )

$\mathrm{CG}-\mathrm{EG}$

$n_{1}=280, n_{2}=285$

Lower critical value

$$
W_{\text {low }}
$$

75436

$\mathrm{CG}-\mathrm{EG}$

$n_{1}=n_{2}=280$

74787

82293

Higher critical value

83044

Table 2.

$$
W_{\text {high. }}
$$

$\mathrm{CG}-\mathrm{EG}$

$n_{1}=n_{2}=285$

b) finding basic quantitative characteristics: 1) average sample value $(\bar{x}) ; 2)$ sample dispersion $\left(S_{x}^{2}\right)$ and standard deviation $\left.\left(S_{x}\right) ; 3\right)$ estimating precision $\left(\delta_{x}\right)$ and confidence interval $\left(\bar{x}-\delta_{x} ; \bar{x}+\delta_{x}\right)$.

c) comparing the average values using Student's ttest $[2,215]$. The empirical value of Student's t-test is measured according to the formula:

$$
T_{\text {obser. }}=\frac{\bar{x}-\bar{y}}{\sqrt{\left(n_{1}-1\right) S_{x}^{2}+\left(n_{2}-1\right) S_{y}^{2}}} \cdot N \text {, }
$$

where $N=\sqrt{\frac{n_{1} n_{2}\left(n_{1}+n_{2}-2\right)}{n_{1}+n_{2}}}$.

In our case $N=282$.

\begin{tabular}{|c|c|c|c|c|c|c|c|}
\hline \multirow{2}{*}{ Components } & \multirow[t]{2}{*}{ Level } & \multicolumn{2}{|c|}{ low } & \multicolumn{2}{|c|}{ medium } & \multicolumn{2}{|c|}{ high } \\
\hline & & $\begin{array}{l}\text { Number of } \\
\text { respondents }\end{array}$ & $\%$ & $\begin{array}{l}\text { Number of } \\
\text { respondents }\end{array}$ & $\%$ & $\begin{array}{l}\text { Number of } \\
\text { respondents }\end{array}$ & $\%$ \\
\hline \multirow[t]{2}{*}{ motivational } & $\mathrm{CG}$ & 113 & 40.36 & 140 & 50.00 & 27 & 9.64 \\
\hline & $\mathrm{EG}$ & 114 & 40.00 & 145 & 50.88 & 26 & 9.12 \\
\hline \multirow[t]{2}{*}{ content } & $\mathrm{CG}$ & 115 & 41.07 & 137 & 48.93 & 28 & 10.00 \\
\hline & EG & 118 & 41.41 & 141 & 49.47 & 26 & 9.12 \\
\hline \multirow[t]{2}{*}{ cognitive } & $\mathrm{CG}$ & 111 & 39.64 & 141 & 50.36 & 28 & 10.00 \\
\hline & EG & 114 & 40.00 & 142 & 49.82 & 29 & 10.18 \\
\hline \multirow[t]{2}{*}{ procedural } & $\mathrm{CG}$ & 109 & 38.93 & 146 & 52.14 & 25 & 8.93 \\
\hline & EG & 112 & 39.30 & 148 & 51.93 & 25 & 8.77 \\
\hline \multirow[t]{2}{*}{ self-evaluating } & $\mathrm{CG}$ & 112 & 40.00 & 141 & 50.36 & 27 & 9.64 \\
\hline & EG & 113 & 39.65 & 144 & 50.53 & 28 & 9.82 \\
\hline \multirow[t]{2}{*}{ reflexive } & $\mathrm{CG}$ & 116 & 41.43 & 134 & 47.86 & 30 & 10.71 \\
\hline & EG & 119 & 41.75 & 136 & 47.72 & 30 & 10.53 \\
\hline \multirow[t]{2}{*}{ creative } & $\mathrm{CG}$ & 130 & 46.43 & 130 & 46.43 & 20 & 7.14 \\
\hline & EG & 132 & 46.32 & 131 & 45.96 & 22 & 7.72 \\
\hline \multirow[b]{2}{*}{ total } & $\mathrm{CG}$ & 114 & 40.71 & 140 & 50.00 & 26 & 9.29 \\
\hline & $\mathrm{EG}$ & 116 & 40.70 & 144 & 50.53 & 25 & 8.77 \\
\hline
\end{tabular}

Cumulative data of maturity levels of the components of preparing future Physical education teachers for health saving technologies at the summative stage of the experiment 
Levels of Control and Experimental Groups Members' Readiness for Using

Table 11 Health Saving Technologies at the Summative Stage of the Experiment

\begin{tabular}{|c|c|c|c|c|}
\hline \multicolumn{2}{|c|}{ level } & low & medium & high \\
\hline \multicolumn{2}{|c|}{ scores } & 3.75 & 6.25 & 8.75 \\
\hline \multirow{3}{*}{ 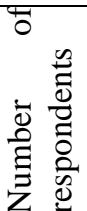 } & $\begin{array}{l}\mathrm{CG}(x) \\
n_{1}=280\end{array}$ & 114 & 140 & 26 \\
\hline & $\begin{array}{l}\mathrm{EG}(y) \\
n_{2}=285\end{array}$ & 116 & 144 & 25 \\
\hline & & 230 & 284 & 51 \\
\hline
\end{tabular}

a) samples homogeneity

1) general ordered sample: 1 . $23230 \quad 231 \ldots 514$ $515 \ldots 565$.

2) $w_{\text {obser. }}=79357$. This value does not go beyond the critical zone boundaries (table 2). The samples are qualitatively homogeneous.

b) quantitative characteristics

1) $\mathrm{CG}(x): \bar{x}=5.47 ; S_{x}^{2}=2.5166 ; S_{x}=1.58$; $\delta_{x}=0.18$;

(5.28; 5.64) - confidence interval.

2) EG $(y): \bar{y}=5.45 ; S_{y}^{2}=2.5077 ; S_{y}=1.58$;

$\delta_{y}=0.18$;

CG

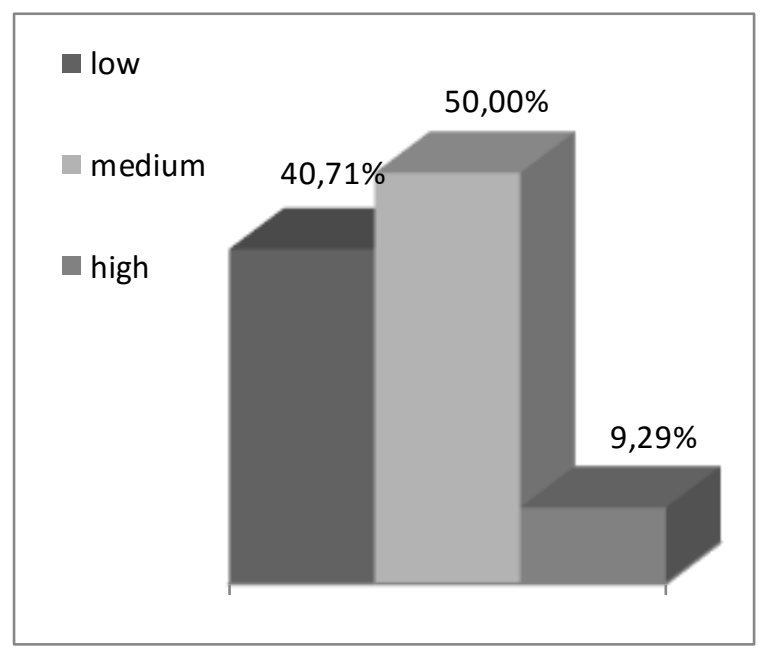

(5.27; 5.63) - confidence interval.

c) comparing the average values using Student's ttest

1)

$T_{\text {obser. }}=\frac{5.47-5.45}{\sqrt{279 \cdot 2.5166+284 \cdot 2.5077}} \cdot 282=0.15$ ;

2) $t_{c r}(0.05 ; 563)=1.96$.

$T_{\text {obser. }}<t_{c r}$. There is no significance difference in the average values.

Fig. 8. The maturity levels of control and experimental groups members' health-saving skills at the summative stage of the experiment

The high level of health saving skills maturity at the summative stage of the experiment was found in $9.03 \%$ of the respondents, among which $49.02 \%$ - the representatives of EG, and $50.98 \%$ - CG.

$50.27 \%$ of the respondents have the medium level (50.43\% - EG and $49.57 \%$ - CG).

The low level of health saving skills maturity was found in $40.71 \%$ of the respondents $(50.43 \%$ - EG, 49.57 - CG).

Science and Education, 2017, Issue 8

\section{Conclusion}

Thus, the carried out analysis of research outcomes shows that the greatest number of the respondents (about $90 \%$ ) have immature level of health saving skills. These students are not aware of the essence and specificity of health saving technologies and peculiarities of their application in the educational process; their skills are primarily focused on the reproduction of traditional methods and approaches; the understanding of the necessity of using 
health saving technologies is considered as nonsense for them; reflexive position is not associated with the understanding of their own style of working with children.

The process of the development of future Physical Education teachers' health saving skills has to be im-

\section{REFERENCES}

1.Aksonova, O. P. (2005). Formuvannia fizychnoi kultury uchniv pochatkovoi shkoly v umovakh dyferentsiiovanoho navchannia [Forming physical culture of school students in terms of differentiated teaching]. Extended abstract of candidate's thesis. Ternopil [in Ukrainian].

2.Hmurman, V. E. (1979). Rukovodstvo k resheniyu zadach po teorii veroyatnostey $i$ matematicheskoy statistike [Study guide to solving tasks in theory of theory of probability in mathematical statistics]. Moscow: Vyssh. Shkola [in Russian].

3. Horashchuk, V. (2003). Formirovanie kultury zdorovya shkolnikov (teoriya i praktika) [Forming culture of health in school students: theory and practice]. Luhansk: Alma-mater [in Russian].

4.Denysenko, N. F. (2002). Teoretychni zasady ta tekhnolohiia upravlinnia systemoiu fizychnoho vykhovannia ditei doshkilnykh navchalnykh zakladiv [Theoretical bases and technology of management of the system of physical education of preschoolers]. Extended abstract of doctor's thesis. Kyiv [in Ukrainian].

5.Dubohai, O. (2001). Rol fizychnoho vykhovannia $\mathrm{u}$ formuvanni zdorovoho sposobu zhyttia [Role of physical education in the formation of healthy way of living]. Molod za zdorovia: Materialy Mizhnarodnoi konferentsii - Youth and health: proceedings of international conference. Kyiv [in Ukrainian].

6. Yermolova, V., Ivanova, L. (2005). Analiz ta otsinka profesiinoi diialnosti vchytelia fizychnoi kultury [Analysis and assessment of professional activity of Physical Education teacher]. Zdorovia ta fizychna kultura Health and physical culture, 17, 11-15 [in Ukrainian].

\section{ЛІТЕРАТУРА}

1. Аксьонова О. П. Формування фізичної культури учнів початкової школи в умовах диференційованого навчання : автореф. дис. на здобуття наук. ступеня канд. пед. наук : спец. 13.00.07 «Теорія і методика виховання» / Олена Петрівна Аксьонова ; Тернопільський національний педагогічний ун-т ім. Володимира Гнатюка. - Тернопіль, 2005. - 20 с.

2. Гмурман В. Е. Руководство к решению задач по теории вероятностей и математической статистике / В. Е. Гмурман. - М. : Высш. школа, 1979. - 400 с.

3. Горащук В. Формирование культуры здоров'я школьников (теория и практика) / В. Горащук. - Луганск : Альма-матер, 2003. - С. 26.

4. Денисенко Н. Ф. Теоретичні засади та технологія управління системою фізичного виховання дітей дошкільних навчальних закладів : автореф. дис. ... дра пед. наук : спец. 13.00.08 «Дошкільна педагогіка»/ Нінель Федорівна Денисенко ; Запорізький обласний proved. There is a need for a methodical system of such a training and relevant pedagogical conditions contributing to the efficiency of the educational process.

7.Zaitsev, H. K. (1998). Shkolnaya valeologiya: pedagogicheskie osnovy obespecheniya zdoroviya uchashchikhsya i uchiteley [School valeology: pedagogical bases of providing health of students and teachers]. $2^{\text {nd }}$ ed. rev. Saint Petersburg: Aktsydent [in Russian].

8. Klymova, V. Y. (1985). Chelovek i ego zdoroviie [Human being and his/her health]. Moscow: Znanye [in Russian].

9. Kovalenko, Yu. O. (2008). Profesiina pidhotovka maibutnikh fakhivtsiv fizychnoho vykhovannia ditei doshkilnoho viku u vyshchykh navchalnykh zakladakh [Professional training of future Physical Education teachers at higher educational institutions]. Extended abstract of candidate's thesis. Zaporizhzhia [in Ukrainian].

10.Lozynskyi, V. (2008). Tekhniky zberezhennia zdorovia [Techniques of saving health]. Kyiv: Hlavnyk [in Ukrainian].

11. Naumenko, Yu. (2005). Zdorovesberehayushchaya deyatelnost shkoly [Health saving activity of school]. Pedagogika - Pedagogy, 6, 37-44 [in Russian].

12. Orzhekhovska, V., Yezhova, O. (2009). Metodolohichni zasady diialnosti osvitnoho zakladu, spriamovanoi na zdorovia [Methodological bases of health saving activities of an educational institution]. Pedahohika $i$ psykholohiia - Pedagogy and psychology, 4, 5-17 [in Ukrainian].

13. Svyrydenko, S., Vashchenko, O. (2007). Formuvannia navychok zdorovoho sposobu zhyttia [Forming healthy way of living skills]. Pochatkova osvita - Primary education, 16, 12-15 [in Ukrainian].

ін-т післядипломної педагогічної освіти. - К., 2002. $39 \mathrm{c}$.

5. Дубогай О. Роль фізичного виховання у формуванні здорового способу життя / О. Дубогай // Молодь за здоров'я : Матеріали Міжнародної конференції. - К. : [Б. в.], 2001. - С. 33.

6. Срмолова В. Аналіз та оцінка професійної діяльності вчителя фізичної культури / В. Срмолова, Л. Іванова // Здоровя та фізична культура. - № 17. 2005. - С. 11-15.

7. Зайцев Г. К. Школьная валеологія : педагогические основы обеспечения здоровья учащихся и учителей / Г. К. Зайцев. - 2-е изд. перераб. и доп. СПб. : Акцидент, 1998. - 159 с.

8. Климова В. И. Человек и его здоровье / В. И. Климова. - М. : Знание, 1985. - 192 с.

9. Коваленко Ю. О. Професійна підготовка майбутніх фахівців фізичного виховання дітей дошкіль- 
ного віку у вищих навчальних закладах : автореф. дис. ... канд. пед. наук : спеціальність 13.00.04 «Теорія та методика професійної освіти» / Юлія Олексіївна Коваленко ; Класичний приватний університет. - Запоріжжя, 2008. - 21 с.

10. Лозинський В. Техніки збереження здоров’я / В. Лозинський. - К. : Главник, 2008. - 160 с.

11. Науменко Ю. Здоровьесберегающая деятельность школы / Ю. Науменко // Педагогика. - 2005. № $6 .-$ C. $37-44$.
12. Оржеховська В. Методологічні засади діяльності освітнього закладу, спрямованої на здоров'я / В. Оржеховська, О. Сжова // Педагогіка і психологія. - 2009. - № 4. - С. 5-17.

13. Свириденко С. Формування навичок здорового способу життя / С. Свириденко, О. Ващенко // Початкова освіта. - 2007. - № 16. - С. 12-15.

Вадим Володимирович Ткаченко, кандидат педагогічних наук, стариий викладач кафедри педагогіки вищої школи і освітнього менеджменту, Черкаського національного університету імені Богдана Хмельницького, Бульвар Шевченка 81, м. Черкаси, Украӥна

\section{ПРОБЛЕМА ГОТОВНОСТІ ДО ЗАСТОСУВАННЯ ЗДОРОВ'ЯЗБЕРЕЖКВАЛЬНИХ ТЕХНОЛОГІЙ МАЙБУТНІМИ ВЧИТЕЛЯМИ ФІЗИЧНОЇ КУЛЬТУРИ}

Складна екологічна ситуація, інтенсифікація та інформаційне перенасичення навчального процесу призвели до значного погіршення здоров’я молоді. Мета статті - перевірка рівня готовності майбутніх учителів фізичної культури до застосування здоров'язбережувальних технологій за рахунок упровадження в навчальний процес теоретичних і методологічних засад підготовки на основі взаємозв'язку мотиваційного, змістового, когнітивного, процесуального, самооцінного, рефлексивного та творчого компонентів шляхом застосування сучасних підходів до організації навчального процесу (дослідницького, особистісно зорієнтованого, технологічного, диференційованого, компетентнісного). Дослідження будувалося на основі аналізу статистичних даних, що відображають результати формування готовності майбутніх учителів фізичної культури до застосування здоров'язбережувальних технологій; результатів науково-педагогічного дискурсу сутності здоров'язбережувальних технологій; узагальнення тенденцій опанування здоров'язбережувальних технологій майбутніми вчителями фізичної культури. Проведений аналіз результатів експерименту дозволяє стверджувати, що переважна більшість його учасників (близько 90\%) мають недостатній рівень готовності до використання здоров'язбережувальних технологій. Процес підготовки майбутніх учителів фізичної культури до застосування здоров’язбережувальних технологій потребує значного вдосконалення; необхідна методична система такої підготовки та відповідні педагогічні умови, які сприятимуть ефективності навчальної діяльності.

Ключові слова: вчитель, готовність, експеримент, здоров'я, здоров'язбережувальні технології, навчальновиховний процес, фізична культура.

Reviewed by Doctor of Pedagogy, prof. S. Danyliuk

Submitted on June, 6, 2017 